\title{
Effect of Substrate Concentration on Soil Enzyme Urease
}

\author{
J. Aruna Kumari ${ }^{1^{*}}$, P.C.Rao ${ }^{2}$, G.Padmaja ${ }^{3}$ and M. Madhavi ${ }^{4}$ \\ ${ }^{1}$ Department of Biochemistry, College of Agriculture, PJTSAU, Rajendranagar, \\ Hyderabad, Telangana, India \\ ${ }^{2}$ Dean of Agricuilture (Retd.) PJTSAU, ${ }^{3}$ Department of SSAC, College of Agriculture, \\ PJTSAU, India \\ ${ }^{4}$ ACRPP, Weed control, Rajendranagar PJTSAU, India \\ *Corresponding author
}

\section{A B S T R A C T}

\begin{tabular}{l} 
K e y w o r d s \\
Alfisols,Eadie - \\
Hofstee \\
Transformation, \\
Hanes - Wolf \\
Transformation, \\
Lineweaver - Burk \\
Transformation, \\
Article Info \\
\hline $\begin{array}{l}\text { Accepted: } \\
\text { 05 February } 2020 \\
\text { Available Online: } \\
\text { 10 March } 2020\end{array}$ \\
\hline
\end{tabular}

To study the effect of substrate concentration on soil enzyme Urease in selected soils. Forty soil samples were assayed to measure the activity of the soil enzyme Urease among them four soil samples two Alfisols and two Vertisolssoils with high activity were selected for further study. Urease activities of the surface soils expressed as $\mu \mathrm{g} \mathrm{of} \mathrm{NH}_{4}{ }^{+}$released gi soil $\mathrm{h}^{-1}$ ranged from 5.9 to 16.0 with an average value of 8.74.Soil enzyme Urease activity increased with an increase in substrate concentration in the beginning and almost reached a plateau at a substrate concentration of $30 \mathrm{mM}$ for all the four soils. With further increase in substrate concentration, minimal change in enzyme activity was observed. Characteristics of enzyme activities like maximum enzyme reaction velocity $\left(\mathrm{V}_{\max }\right)$ and Michaelis constant $\left(\mathrm{K}_{\mathrm{m}}\right)$ were determined using Michealis - Menten equation similar to those determined in homogenous system. The $\mathrm{Km}$ value range from $0.49 \mathrm{mM}$ to $0.60 \mathrm{mM}$ in Lineweaver - Burk Transformation and $0.50 \mathrm{mM}$ to $0.76 \mathrm{mM}$ in Hanes - Wolf Transformation and in case of Eadie - Hofstee Transformation the $\mathrm{Km}$ value range from $0.62 \mathrm{mM}$ to $0.78 \mathrm{mM}$. Vertisols showed more $\mathrm{km}$ value than Alfisols. The Vmax value range from $8.1 \mu \mathrm{g}$ of $\mathrm{NH}_{4}{ }^{+}$released $\mathrm{g}^{-1}$ soil $\mathrm{h}^{-1}$ to $10 \mu$ gof $\mathrm{NH}_{4}{ }^{+}$released $\mathrm{g}^{-1}$ soil h${ }^{-1}$ in Lineweaver - Burk Transformation and 8.7 $\left(\mu \mathrm{g}\right.$ of $\mathrm{NH}_{4}{ }^{+}$released $\mathrm{g}^{-1}$ soil $\mathrm{h}^{-1}$ to 10.3 ( $\mu \mathrm{g}$ of $\mathrm{NH}_{4}^{+}$released g ${ }^{-1}$ soil $\mathrm{h}^{-1}$ in Hanes - Wolf Transformation and in case of Eadie - Hofstee Transformation the max range from 9.1 $\left(\mu \mathrm{g}\right.$ of $\mathrm{NH}_{4}{ }^{+}$released $\mathrm{g}^{-1}$ soil $\mathrm{h}^{-1}$ to $10.5(\mu \mathrm{g}$ of $\mathrm{NH}_{4}{ }^{+}$released $\mathrm{g}^{-1}$ soil $\mathrm{h}^{-1}$. Vmax value range from $8.1\left(\mu \mathrm{g}\right.$ of $\mathrm{NH}_{4}{ }^{+}$released $\mathrm{g}^{-1}$ soil ${ }^{-1}$ to 9.7 $\left(\mu \mathrm{g}\right.$ of $\mathrm{NH}_{4}^{+}$released $\mathrm{g}^{-1}$ soil $\mathrm{h}^{-1}$ in Vertisols and $9.5\left(\mu \mathrm{g} \mathrm{of} \mathrm{NH}_{4}^{+}\right.$released $\mathrm{g}^{-1}$ soil $\mathrm{h}^{-1}$ to $10.5\left(\mu \mathrm{g}\right.$ of $\mathrm{NH}_{4}{ }^{+}$released $\mathrm{g}^{-1}$ soil $\mathrm{h}^{-1}$ in Alfisols and Alfisols showed more Vmax value than Vertisols

\section{Introduction}

The enzyme Urease (urea amidohydrolase, EC 3.5.1.5) is the enzyme that catalyzes the hydrolysis of urea to $\mathrm{CO}_{2}$ and $\mathrm{NH}_{4}$ (Reithel, F.J. 1971). It is not involved in $\mathrm{N}$ mineralization in soils. This enzyme catalyzes the hydrolysis of urea, added to soils as a fertilizer. It breaks the $\mathrm{C} / \mathrm{N}$ bonds other than peptide bonds in linear amides and releases $\mathrm{NH}_{4}$ (Ladd and Jackson, 1982; Tabatabai, 1994); thus, belongs to a group of enzymes that include glutaminase and amidase. Urease activity in soil is influenced by many factors 
including crop history, organic matter, heavy metals, soil temperature, $\mathrm{pH}$, soil amendments etc. (Yang et al., 2006).

The two most remarkable properties of enzymes are their specificity and their catalytic efficiency, and it is in these properties that enzymes differ most strikingly from simple catalysts. When it is possible, to compare the enzymatic rates with their own non-enzymatic counterparts, one finds that enzymes enhance the reaction by several orders of magnitude (Segel, 1975).

Soil enzymes are largely immobilized enzymes in soil colloidal particle and hence are different from homogenous systems. Nevertheless, with small substrates, the rate of reactions is not expected to be very much reduced as most of the diffusion mobility resides with the substrate.

Theories and mathematical analysis of enzyme reactions are based on the concept that an enzyme acts by forming a complex or compound with substrate presumably the complex of enzyme and substrate is unstable and proceeds through one or more steps or rearrangement to form the product plus the original enzyme. This theory of enzyme was proposed by Michaelis and Menten and may be expressed by the following equation:

$$
S+E \underset{K 2}{\stackrel{K 1}{\leftrightarrows}} E S \stackrel{K 3}{\rightarrow} E+P \ldots(1)
$$

Where $\mathrm{S}$ is the substrate, $\mathrm{E}$ is the enzyme, ES is the intermediate enzyme-substrate complex, $\mathrm{P}$ is the product of the reaction and $\mathrm{K}_{1}, \mathrm{~K}_{2}$ and $\mathrm{K}_{3}$ are the respective reaction velocity constants or rate constant of the three processes.

It can be shown that with the soluble substrate in excess, the rate of reaction, that is, the decrease in concentration of the substrate with time or the increase in concentration of the product is given by:

$$
-\frac{d s}{d t}=\frac{d p}{d t}=k_{3}[E S]=\frac{k_{3}[E][S]}{K_{m}+[S]}=\frac{V_{\max }[S]}{K_{m}+[S]}
$$

Where $\mathrm{S}$ and ES are the concentration of substrate and enzyme-substrate complex respectively, $\mathrm{K}_{\mathrm{m}}$ is Michaelis constant.

$$
\begin{gathered}
K_{m}=\frac{K_{2}+K_{3}}{K_{1}} \\
V_{\text {max }}=K_{3} E
\end{gathered}
$$

$\mathrm{K}_{\mathrm{m}}$ is equal to substrate concentration (expressed in moles per liter) at $\mathrm{V}=\mathrm{V}_{\max } / 2$. When $\mathrm{K}_{2}$ is greater than $\mathrm{K}_{3}, \mathrm{~K}_{\mathrm{m}}$ may be set equal to dissociation constant $\left(\mathrm{K}_{2} / \mathrm{K}_{1}\right)$ of enzyme-substrate complex and $1 / K_{m}$ then becomes the affinity constant. Although these equations are basic, it must be kept in mind that $\mathrm{pH}$, ionic strength, temperature and many other factors influence the values of $\mathrm{K}_{1}, \mathrm{~K}_{2}$ and $K_{3}$ (Irving and Cosgrove, 1976). For the experimental determination of $\mathrm{V}_{\max }$ and $\mathrm{K}_{\mathrm{m}}$ linear form of the Michaelis-Menten equation are generally used.

The three linear transformations that commonly used are:

$$
\text { 1. } \frac{1}{V}=\frac{1}{\begin{array}{c}
V_{\max } \\
\text { Lineweaver-Burk }
\end{array}}+\frac{K_{m}}{V_{\max }} \cdot \frac{1}{[s]}
$$

2. $\frac{[s]}{V}=\frac{K_{m}}{V_{\max }}+\frac{1}{V_{\max }} \cdot[S]$

Hanes-Wolf transformation

$$
\text { 3. } V=V_{\max }-K_{m} \frac{V}{[s]}
$$

Eadie-Hofstee transformation

Plots of the variables of such relationships normally give straight lines. The value of the slope and intercept are commonly used for 
determination of the constants from a set of experimental data. Once the $\mathrm{K}_{\mathrm{m}}$ and $\mathrm{V}_{\max }$ are known for a particular enzymatic reaction under a given set of conditions, the reaction velocity, $\mathrm{V}$ can be calculated for any substrate concentration. The Michaelis constant is by far the most fundamental constant in enzyme chemistry. It has the dimensions of concentration (that is, moles per liter) and it is a constant for the enzyme only under rigidly specified conditions. The $\mathrm{K}_{\mathrm{m}}$ value is useful in estimating the substrate concentration necessary to give a maximum velocity.

Kinetic parameters $\left(\mathrm{V}_{\max }\right.$ and $\left.\mathrm{K}_{\mathrm{m}}\right)$ are often used to characterize free enzymes in solution, they are consideredto be constant for a specific enzyme under defined experimental conditions (Marx et al., 2005), but they may vary independently. Maximum reaction velocity $\left(\mathrm{V}_{\max }\right)$ of an enzyme catalyzed reaction simply splitting velocity or rate of dispersion of enzyme-substrate complex into enzyme and reaction products, which reflects the conjunction affinity between enzyme and substrate.

The higher or lower $\mathrm{V}_{\max }$ value can be used as an indicator to a speedy or slow enzymatic process. $\mathrm{V}_{\max }$ and $\mathrm{K}_{\mathrm{m}}$ of an enzyme express the quantity of an enzyme and substrate affinity, respectively (Marx etal., 2005).

However, Michaelis constant $\left(\mathrm{K}_{\mathrm{m}}\right)$ represents the endurance of an enzyme-substrate complex, which is related with the substrate. The efficiency of the enzymesto decompose substrate at low concentration is directly related to their $\mathrm{K}_{\mathrm{m}}$ value (Marx et al., 2005). Higher is the endurance of an enzymesubstrate complex, lower will be the $\mathrm{K}_{\mathrm{m}}$ value. Enzymes catalyzing the same reaction, but derived from different sources of soil have different $\mathrm{K}_{\mathrm{m}}$ values (Nannipieriet al., 1990). Besides, $\mathrm{K}_{\mathrm{m}}$ is independent of enzyme concentration and kinetically reflects the apparent affinity of enzyme for the substrate. In other words, smaller the $\mathrm{K}_{\mathrm{m}}$ value, the greater will be the affinity for the substrate (Masciandaro et al., 2000). However, estimating $\mathrm{K}_{\mathrm{m}}$ is challenging due to the uncertainty regarding the relative contribution of artificial and naturally occurring substrate under nonsaturating conditions (Stone et al., 2011).

Moreover, enzymes may operate under nonsaturating conditions in soil, which supplements $\mathrm{K}_{\mathrm{m}}$ an important parameter that merits increased attention (Davidson et al., 2006 and German et al., 2011). If substrate concentration is similar to $\mathrm{K}_{\mathrm{m}}$, the measure of affinity for substrate/enzyme can provide information about the adsorption level or enzyme accessibility.

Besides, $\mathrm{K}_{\mathrm{m}}$ influences enzyme activity at low substrate concentration (Davidson and Janssens, 2006 and Davidson et al., 2006). Many investigations have dealt with the kinetic properties of enzymes (Masciandaro et al., 2000, Zhang et al., 2009 and 2010, Juan et al., 2010).

Although, the literature on soil enzyme is on the increase, reports on kinetic constants like Michaelis constant and $\mathrm{V}_{\max }$ and their correlations with soil properties are limited. Values for both $\mathrm{K}_{\mathrm{m}}$ and $\mathrm{V}_{\max }$ vary with the type of soil and also its physical fractions. Then, values are also influenced by assay conditions like choice of substrate and buffer, use of shaken or unshaken soil suspensions.

When the Michaelis-Menten model is applied to ecological systems, $V_{\max }$ and $\mathrm{K}_{\mathrm{m}}$ no longer reflect the biochemical attributes defined in its original context. In such cases, these parameters are more accurately described as apparent $\mathrm{V}_{\max }\left(\mathrm{App} \mathrm{V}_{\max }\right)$ and apparent $\mathrm{K}_{\mathrm{m}}$ $\left(\mathrm{AppK}_{\mathrm{m}}\right)$ with $\mathrm{App} \mathrm{V}_{\max }$, a relative measure of enzyme abundance, and $\mathrm{AppK}_{\mathrm{m}}$, a relative 
measure of substrate (Wallenstein et al., 2011).

$K_{m}$ and $V_{\max }$ values for ureases of different particle size fractions of soils differed from each other and from those of unfractionated soils (Tabatabai, 1973). Generally the $\mathrm{K}_{\mathrm{m}}$ values of fractions were greater than those of unfractionated soils but no relationship of these values with particle size could be so established. $\mathrm{V}_{\max }$ values of all fractions were considerably less than those of the unfractionated soils, indicative of urease destruction, perhaps during the sonic vibrating the fractions.

$\mathrm{K}_{\mathrm{m}}$ values may also fluctuate, depending on whether it is in the free or in an absorbed state (McLaren and Packer, 1970). While investigating the enzyme splitting of urea in the presence of bentonite, Durand, (1966), obtained higher $\mathrm{K}_{\mathrm{m}}$ values for adsorbed than for free enzyme. $K_{m}$ values also varied with $\mathrm{pH}$ of assay, being lowest at the $\mathrm{pH}$ optimum. In general $\mathrm{K}_{\mathrm{m}}$ for soil enzymes are greater than that for the corresponding pure enzymes. Paulson and Kurtz, (1970), indicating a much lower apparent affinity of the adsorbed enzyme for the substrate compared to that of the native enzyme. Shaking of soil suspension during assay decreased $\mathrm{K}_{\mathrm{m}}$ values and increased $\mathrm{V}_{\max }$ values for soil urease (Tabatabai, 1973).

\section{Materials and Methods}

Urease activity was assayed by quantifying the rate of release of NH4+ from the hydrolysis of Urea as described by Tabatabai and Bremner (1972), but with some modifications as suggested by Dorich and Nelson (1983) and Rao (1989). Urea solution $(0.2 \mathrm{M})$ : This was obtained by dissolving 1.2 $\mathrm{g}$ of Urea in $80 \mathrm{ml}$ distilled water and volume was made up to $100 \mathrm{ml}$. Potassium chloride (2 M) - Silver Sulphate (100 ppm) KCl-Ag2SO4 solution: $100 \mathrm{mg}$ of $\mathrm{Ag}_{2} \mathrm{SO}_{4}$ was dissolved in $700 \mathrm{ml}$ of distilled water to which $300 \mathrm{ml}$ of water containing $149 \mathrm{~g}$ of $\mathrm{KCl}$ was added. $\mathrm{MgO}$ : Magnesium oxide was heated in an electrical furnance at $500^{\circ} \mathrm{C}$ for an hour and the powder was collected in dessicator and stored in a tightly stoppered bottle.

4\% Boric acid: $40 \mathrm{~g}$ of Boric acid was dissolved in a beaker containing hot distilled water about $800 \mathrm{ml}$. Then $5 \mathrm{ml}$ bromocresol green and $15 \mathrm{ml}$ of methyl red were added and the volume was made up to 1 litre with hot distilled water. $0.005 \mathrm{~N} \mathrm{H}_{2} \mathrm{SO}_{4}$ : This solution was prepared by taking $5 \mathrm{ml}$ of $1 \mathrm{~N}$ $\mathrm{H}_{2} \mathrm{SO}_{4}$ is taken in a 1 litre volumetric flask and make up to the mark by the addition of distilled water. Soil samples $(5 \mathrm{~g})$ were taken in $50 \mathrm{ml}$ capacity glass tubes to which $9 \mathrm{ml}$ distilled water was added.

Substrate i.e. urea solution of $\mathrm{mM}$ strength were added to different glass tubes in triplicates so as to obtain 1, 2, 3, 4, 5, 10, 20, 30, 40 and $\mathrm{mM}$ urea in the glass tubes. These tubes were made air tight and were incubated for 2 hours at $37^{\circ} \mathrm{C}$. Thereaction was terminated by the addition of $\mathrm{KCl}-\mathrm{Ag}_{2} \mathrm{SO}_{4}$. The contents were agitated on mechanical shaker for one hour to release all $\mathrm{NH} 4+$ formed and the suspension was allowed to settle. Thirty $\mathrm{ml}$ of the supernatant with $\mathrm{KCl}-$ $\mathrm{Ag}_{2} \mathrm{SO}_{4}$ extract was taken and transferred to Kjeldahl flask.

To this a pinch of $\mathrm{MgO}$ was added which was kept at one end of the distillation unit. During steam distillation for $4 \mathrm{~min}$, the solution containing $\mathrm{MgO}$ was heated. The ammonia was released into boric acid containing mixed indicator through a tube dipped in the solution. The ammonia released would change the color of the solution from pink to pale green at the end of the distillation. This was titrated against standardized $0.005 \mathrm{~N}$ $\mathrm{H}_{2} \mathrm{SO}_{4}$ and the amount released was 
calculated and expressed as $\mu \mathrm{g}$ of $\mathrm{NH} 4+$ released g-1 soil h-1.

\section{Results and Discussion}

Soil urease activity increased with an increase in substrate concentration in the beginning and almost reached a plateau at a substrate concentration of $30 \mathrm{mM}$ for all the four soils studied (Table 1).With further increase in substrate concentration, minimal change in enzyme activity was noticed. Similar results were obtained by Rao, (1989), andVandana,(2012) for soil urease.

The $\mathrm{V}_{\max }$ and $\mathrm{K}_{\mathrm{m}}$ values were determined using the three linear transformations of the Michaelis-Menten's equation.Lineweaver Burk transformation plot of 1/V against 1/[S], Hanes - Wolf transformation plot of $[\mathrm{S}] / \mathrm{V}$ against $[\mathrm{S}]$ and Eadie - Hofstee transformation plot of $\mathrm{V}$ against $\mathrm{V} /[\mathrm{S}]$ for the four different soils were shown.

From the graphs, it was observed that with all the soils, reasonably linear plots were obtained in all the cases. The values of $\mathrm{V}_{\max }$ and $\mathrm{K}_{\mathrm{m}}$ obtained from the least square analysis of these plots are presented.

The maximum reaction velocity of soil urease for soils understudy when calculated as $\mu \mathrm{g}$ of $\mathrm{NH}_{4}^{+} \mathrm{g}^{-1} \mathrm{~h}^{-1}$ varied from 8.1 to 10.5 and followed the sequence AS II > ASI > VS I > VS II under Lineweaver - Burk plot. The values compared well with Hanes - Wolf transformation (8.7 to 10.3) and followed the sequence AS I > AS II > VS I > VSII under and Eadie - Hofstee transformation the values varied from (9.1 to 10.5) and followed the order AS I > AS II > VS I > VS II. Michaelis constant $\left(\mathrm{K}_{\mathrm{m}}\right)$ of the soil urease calculated using Lineweaver - Burk transformation plot varied from $0.49 \mathrm{mM}$ to $0.60 \mathrm{mM}$.The values compared well with those obtained from Hanes - Wolf (0.50 to 0.76) and followed the sequence of Eadie - Hofstee (0.62 to 0.78) plots. In all the three linear plots the same order is followed the sequence is VS II > VS I $>$ ASI > AS II. These values compared well with the findings of Rao, (1989), Vandana,(2012) and Zhang, (2009) found the influence of soil moisture on $\mathrm{K}_{\mathrm{m}}$ values. Juan et al., (2010) found higher $\mathrm{Km}$ values for soil urease than observed from pure enzymes.This could be due to the difference in physico chemical characteristics of soils. Higher organic carbon content and clay humus complex traps soil urease and slows down the diffusion to substrate, which prevents the urease from interacting with substrate.

McLaren and Packer, (1970) and Vandana, (2012) were of the view that $K_{m}$ values may also fluctuate depending upon whether it is in the free or in an absorbed state. While investigating the enzyme splitting of urea in the presence of bentonite, Durand, (1966) obtained higher $\mathrm{K}_{\mathrm{m}}$ values for adsorbed enzymes than for free enzyme.

Paulson and Kurtz, (1970)and Vandana, (2012) indicated a much lower apparent affinity of the enzyme for the substrate compared to that of the native enzyme. Different $K_{m}$ and $V_{\text {max }}$ values for different soil types for soil urease were obtained by (Tabatabai and Bremner, 1971., Nor, 1982., Rao,1984.,Vandana, 2012).

Kinetic constants may also differ with origin of the enzyme. Frankenberger and Tabatabai,(1982) and Stevenson, (1994), reported that urease of plant origin has different kinetic constants than that of the native soil enzyme. Also, urease of microbial origin differed in the properties from that released by soil microflora. 
Table.1 Effect of substrate concentration on soil urease activity

\begin{tabular}{|c|c|c|c|c|}
\hline \multirow{2}{*}{$\begin{array}{c}\text { Substrate } \\
\text { Concentration } \\
(\mathbf{m M})\end{array}$} & \multicolumn{4}{|c|}{ Urease activity $\left(\boldsymbol{\mu g}\right.$ of $\mathbf{~ N H}_{\mathbf{4}}{ }^{+}$released $\mathbf{g}^{-\mathbf{1}}$ soil $\left.\mathbf{~ h}^{\mathbf{- 1}}\right)$} \\
\hline $\mathbf{1 . 0}$ & VS1 & VS2 & AS1 & AS2 \\
\hline $\mathbf{2 . 0}$ & 4.8 & 5.3 & 6.4 & 5.9 \\
\hline $\mathbf{3 . 0}$ & 6.2 & 6.6 & 7.9 & 7.2 \\
\hline $\mathbf{4 . 0}$ & 6.8 & 7.5 & 8.3 & 7.9 \\
\hline $\mathbf{5 . 0}$ & 7.4 & 7.8 & 8.8 & 8.4 \\
\hline $\mathbf{1 0 . 0}$ & 7.8 & 8.1 & 9.3 & 8.8 \\
\hline $\mathbf{2 0 . 0}$ & 8.2 & 8.5 & 9.7 & 9.3 \\
\hline $\mathbf{3 0 . 0}$ & 8.4 & 8.8 & 9.9 & 9.5 \\
\hline $\mathbf{4 0 . 0}$ & 8.6 & 9.2 & 10.4 & 9.7 \\
\hline $\mathbf{5 0 . 0}$ & 8.7 & 9.3 & 10.5 & 9.9 \\
\hline
\end{tabular}

Table.2 Maximum enzyme reaction velocity $\left(\mathrm{V}_{\max }\right)$ and Michaelis Constant $\left(\mathrm{K}_{\mathrm{m}}\right)$ values of soil urease activity

\begin{tabular}{|c|c|c|c|c|c|c|}
\hline \multirow[t]{2}{*}{ Soils } & \multicolumn{3}{|c|}{$\begin{array}{l}\text { Maximum Enzyme Reaction Velocity }\left(\mathrm{V}_{\max }\right)\left(\mu \mathrm{g} \text { of } \mathrm{NH}_{4}{ }^{+}\right. \\
\left.\text {released } \mathrm{g}^{-1} \text { soil }^{-1}\right)\end{array}$} & \multicolumn{3}{|c|}{ Michaelis Constant $\left(K_{m}\right)(\mathbf{m M})$} \\
\hline & $\begin{array}{c}\text { Lineweaver - } \\
\text { Burk } \\
\text { Transformation }\end{array}$ & $\begin{array}{c}\text { Hanes - } \\
\text { Wolf } \\
\text { Transformation }\end{array}$ & $\begin{array}{c}\text { Eadie - } \\
\text { Hofstee } \\
\text { Transformation }\end{array}$ & $\begin{array}{c}\text { Lineweaver - } \\
\text { Burk } \\
\text { Transformation }\end{array}$ & $\begin{array}{c}\text { Hanes - } \\
\text { Wolf } \\
\text { Transformation }\end{array}$ & $\begin{array}{c}\text { Eadie - } \\
\text { Hofstee } \\
\text { Transformation }\end{array}$ \\
\hline VS I & 9.1 & 9.5 & 9.7 & 0.54 & 0.70 & 0.70 \\
\hline VS II & 8.1 & 8.7 & 9.1 & 0.60 & 0.76 & 0.78 \\
\hline AS I & 9.5 & 10.3 & 10.5 & 0.51 & 0.58 & 0.63 \\
\hline AS II & 10.0 & 10.1 & 10.3 & 0.49 & 0.50 & 0.62 \\
\hline
\end{tabular}

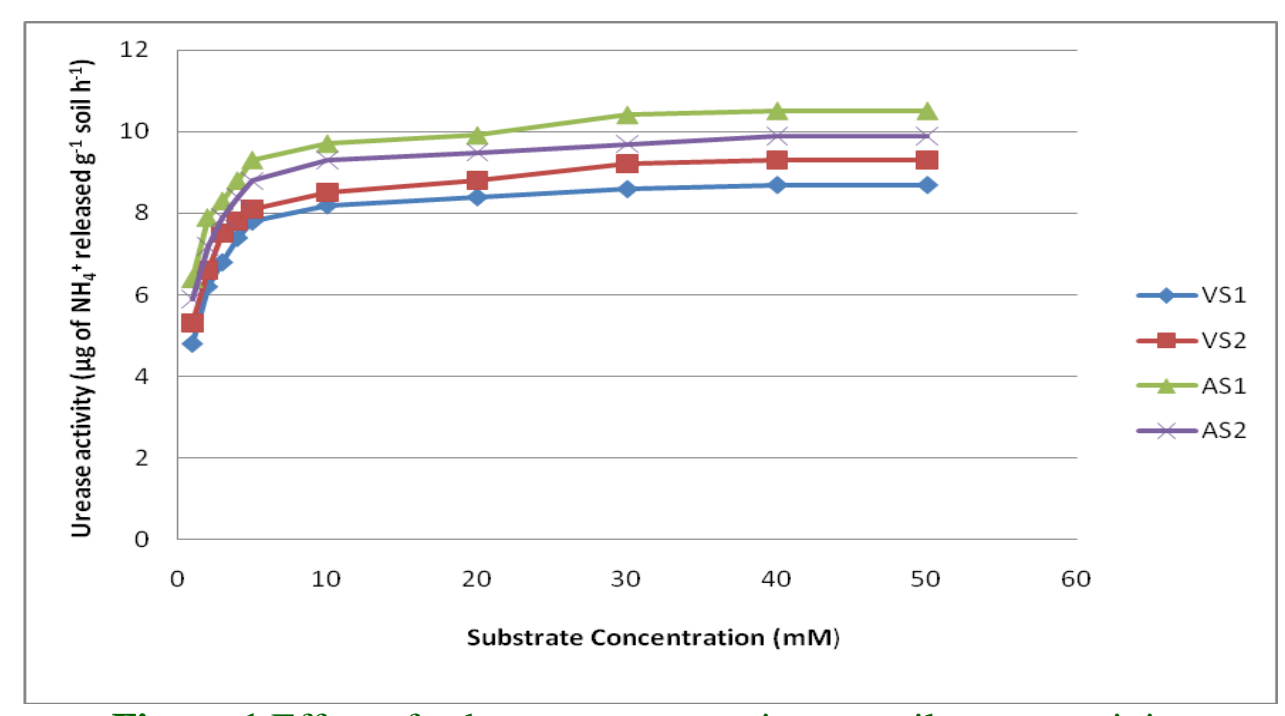

Figure.1 Effect of substrate concentration on soil urease activity 
Int.J.Curr.Microbiol.App.Sci (2020) 9(3): 1150-1158

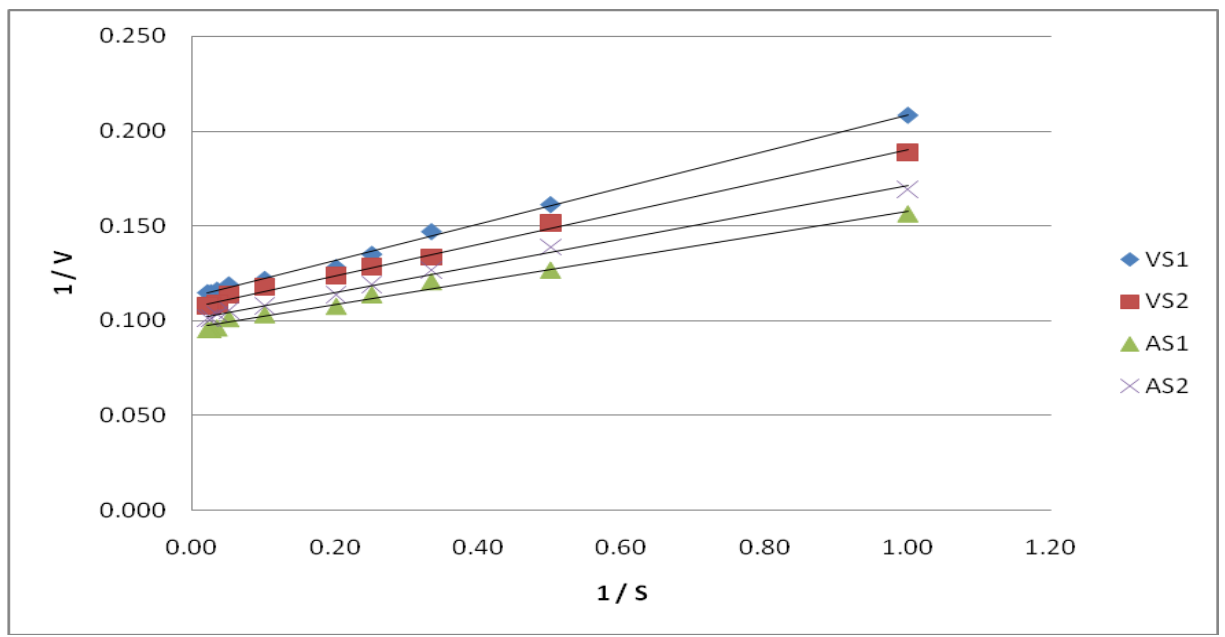

Figure.2 Lineweaver - Burk plot of soil urease activity

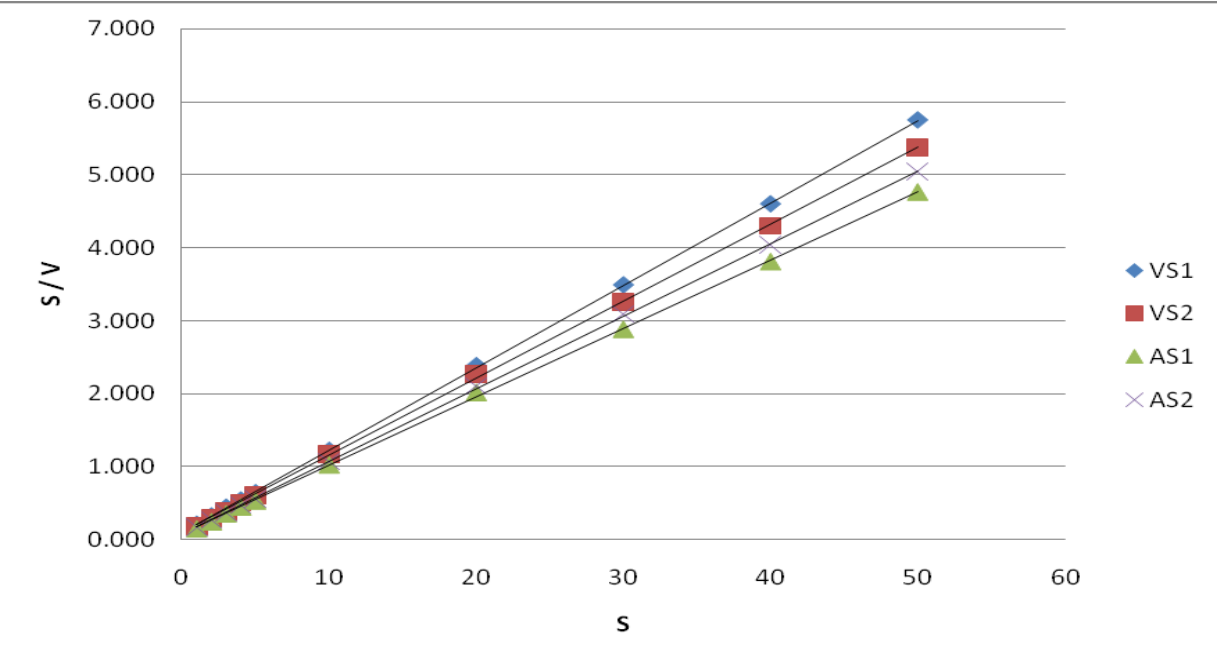

Figure.3 Hanes - Wolf plot of soil urease activity

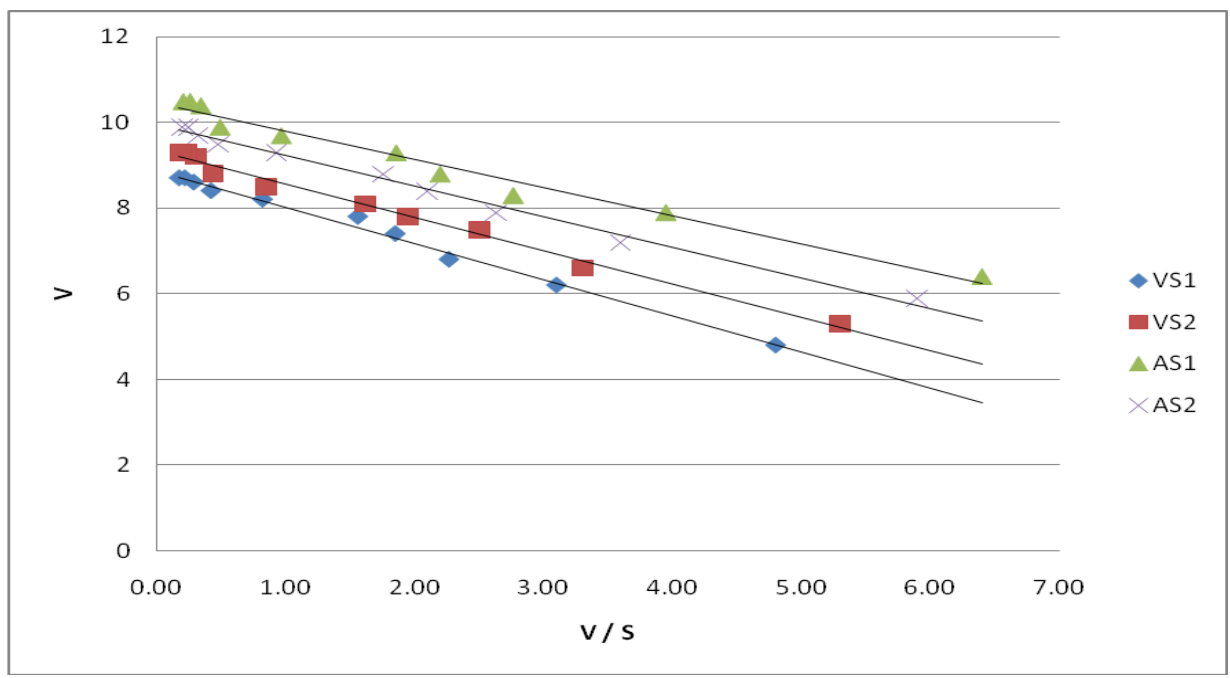

Figure.4 Eadie - Hofstee plot of soil urease activity 
In the beginning of the reaction the active sites of the enzymes were not occupied by the substrate molecules hence as we increase the substrate concentration the rate of the reaction increases following first order kinetics and on further increase the rate of the reaction increase slowly as the active sited are nearly saturated following mixed order kinetics and on further increase of substrate concentration the rate of the reaction is independent of substrate concentration and follows zero order kinetics.

The $\mathrm{Km}$ value range from $0.49 \mathrm{mM}$ to $0.60 \mathrm{mM}$ inLineweaver - Burk Transformation and $0.50 \mathrm{mM}$ to $0.76 \mathrm{mM}$ in Hanes - Wolf Transformation and in case of Eadie - Hofstee Transformation the $\mathrm{Km}$ value range from $0.62 \mathrm{mM}$ to $0.78 \mathrm{mM}$. Vertisols showed more $\mathrm{km}$ value than Alfisols. The Vmax value range from $8.1 \mu \mathrm{g}$ of $\mathrm{NH}_{4}{ }^{+}$released $\mathrm{g}^{-1}$ soil $\mathrm{h}$ ${ }^{1}$ to $10 \mu$ gof $\mathrm{NH}_{4}{ }^{+}$released $\mathrm{g}^{-1}$ soil $\mathrm{h}^{-1}$ in Line weaver - Burk Transformation and 8.7( $\mu \mathrm{g}$ of $\mathrm{NH}_{4}{ }^{+}$released $\mathrm{g}^{-1}$ soil ${ }^{-1}$ to $10.3\left(\mu \mathrm{g}\right.$ of $\mathrm{NH}_{4}{ }^{+}$ released $\mathrm{g}^{-1}$ soil $\mathrm{h}^{-1}$ in Hanes - Wolf Transformation and in case of Eadie - Hofstee Transformation the max range from 9.1 $(\mu \mathrm{g}$ of $\mathrm{NH}_{4}{ }^{+}$released $\mathrm{g}^{-1}$ soil $\mathrm{h}^{-1}$ to $10.5\left(\mu \mathrm{g}\right.$ of $\mathrm{NH}_{4}{ }^{+}$ released $\mathrm{g}^{-1}$ soil $\mathrm{h}^{-1}$.

Vmax value range from $8.1\left(\mu \mathrm{g}\right.$ of $\mathrm{NH}_{4}^{+}$ released g ${ }^{-1}$ soil $\mathrm{h}^{-1}$ to $9.7\left(\mu \mathrm{g}\right.$ of $\mathrm{NH}_{4}^{+}$released $\mathrm{g}^{-1}$ soil $\mathrm{h}^{-1}$ in Vertisols and $9.5\left(\mu \mathrm{g}\right.$ of $\mathrm{NH}_{4}{ }^{+}$ released $\mathrm{g}^{-1}$ soil $\mathrm{h}^{-1}$ to $10.5\left(\mu \mathrm{g}\right.$ of $\mathrm{NH}_{4}^{+}$ released $\mathrm{g}^{-1}$ soil $\mathrm{h}^{-1}$ in Alfisols and Alfisols showed more Vmax value than Vertisols.

\section{References}

Bremner, J.M and Mulvaney, R.L. 1978. Urease activity in soils.In R.G. Burns (eds.) - Soil Enzymes, Academic Press Inc, New York.

Conrad, J.P. 1942. The occurrence and origin of urease activities in soils.Soil Science. 54: $367-380$.

Davidson, E.A., and I.A. Janssens. 2006. Temperature sensitivity of soil carbon decomposition and feedbacks to climate change. Nature 440:165-173.

Dorich, R.A and Nelson, D.W. 1983. Direct colorimetric measurement of ammonium in potassium chloride extracts of soil. Soil Science Society of American Journal. 47(4): $833-836$.

Durand, G. 1966. Ph. D. Thesis submitted to Univ Toulouse. In R.G. Burns (eds.) - Soil Enzymes, Academic Press Inc, New York.

Frankenberger, W.T Jr and Tabatabai, M.A. 1982.Amidase and urease activities in plants.Plant and Soil. 64: 153 - 166.

German, D.P., Weintraub, M.N., Grandy, A.S., Lauber, C.L., Rinkes, Z.L., Allison, S.D., 2011. Optimization of hydrolytic and oxidative enzyme methods for ecosystem studies.Soil Biology \& Biochemistry 43, $1387 \mathrm{e} 1397$.

Irving, G.C and Cosgrove, D.J. 1976. The kinetics of soil acid phosphatase.Soil Biology and Biochemistry. 8: 335-340.

Juan, Y.H., Chen, Z.H., Chen, L.J., Wu, Z.J., Wang, R., Sun, W.T and Zhang, Y.L. 2010.Kinetic and thermodynamic behaviors of soil urease as affected by urease inhibitors.R.C SueloNutr. Veg. 10(1): 1-11.

Ladd, J.N. and Jackson, R.B. 1982: Biochemistry of ammonification. In Nitrogen in Agricultural Soils, Ed. F.J. Stevenson, J.M. Bremner, R.D. Hauck, and D.R. Keeney, No. 22, p. 186-187, Madison, Wisconsin, U.S.A.

Marx, M.C., E. Kandeler, M. Wood, N. Wermbter, and S.C. Jarvis. 2005. Exploring the enzymatic landscape: distribution and kinetics of hydrolytic enzymes in soil particle size fractions. Soil Biology and Biochemistry 37:35-48.

Masciandaro, G., B. Ceccanti, and V. Ronchi. 2000. Kinetic parameters of dehydrogenase in the assessment of the response of soil to vermicompost and inorganic fertilizers. Biology and Fertility of Soils 32:479-483

McLaren, A.D and Packer, E. 1970.Some aspects of Enzyme reactions in heterogeneous systems.In R.G. Burns (eds.) - Soil Enzymes, Academic Press Inc, New York.

Nanniepieri P., Grego S and Ceccanti B. 1990. Ecological significance of the biological activity in soil. Int. J. M. Bollag and G. Stotzky 
(Eds.).Soil Biochemistry.6: 293- 355.

Nor, Y.M. 1982.Soil urease activity and kinetics.Soil Biology and Biochemistry. 14: $63-66$.

Paulson, K.N and Kurtz, L.T. 1970. Michaelis constant of soil urease.Soil Science Society of America Journal. 34: 70-72.

Pettit, N.M., Smith, A.R.J., Freedman, R.B and Burns, R.G. 1976.Soil urease activity stability and kinetic properties.Soil Biology and Biochemistry. 8: 479-484.

Rao, S.V. 1989. Distribution, Kinetics and some interactions of urease and phosphatases in soils. Ph.D. Thesis. Acharya N G Ranga Agricultural University, Hyderabad.

Reithel, F.J. 1971. Ureases.In P.D. Boyer (eds.) The Enzymes, Vol IV, Academic Press Inc, New York.

Segel, I.H. 1975. Enzyme kinetics.John Wiley and Sons Inc, New York.

Stevenson, F.J. 1994. Humus chemistry, Genesis, Composition and reactions.John Wiley and Sons.Newyork.

Stone, M.M., Weiss, M.S., Goodale, C.L., Fernandez, I.J and Allison, S.D. 2011.Temperature sensitivity of soil enzyme kinetics under $\mathrm{N}$-fertilization in two temperate forests.Global Change Biology.1-13.

Tabatabai, M.A and Bremner, J.M. 1971. Michaelis constants of soil enzymes.Soil Biology and Biochemistry. 3: 317-323

Tabatabai, M.A and Bremner, J.M. 1972. Assay of urease activity in soils. Soil Biology and Biochemistry. 4: 479-487.

Tabatabai, M.A. 1973. Michaelis constants of urease in soil and soil fractions. Soil Science Society of American Proceedings.37: 707 711.
Tabatabai, M.A. 1994. Microbiological and biochemical properties. In R.W. Weaver, J.S. Angle and P.S. Bottomley (eds.) Methods of Soil Analysis, Part 2, Soil Enzymes, Soil Science Society, Society of .America. Madison. 775 - 833.

Vandana, J.L. 2012.Urease and phosphomonoesterase activities in soil their distribution, kinetics and influence of management practices on their activities.Ph $D$ Thesis.Acharya N G Ranga Agricultural University, Hyderabad

Wallenstein, M., Allison, S.D., Ernakovich, J., Steinweg, J.M and Sinsabaugh, R. 2011. Controls on the temperature sensitivity of soil enzymes: A Key Driver of In Situ Enzyme Activity Rates. In Shukla and A. Varma (eds.), Soil Enzymology, Soil Biology 22, Springer-Verlag, Berlin, Heidelberg. $245-258$.

Yang, Z., Liu, S., Zheng, D and Feng, S. 2006. Effects of cadium, zinc and lead on soil enzyme activities. Journal of Environmental Science. 18(6): 1135 - 1141.

Zhang, Y.L., Chen, L.J., Sun, C.X., Li, D.P., Wu, Z.J and Duan, Z.H. 2010.Kinetic and thermodynamic properties of hydrolases in Northeastern China soils as affected by temperature.Agrochemica.54 (4): $231 \quad-$ 242.

Zhang, Y.L., Sun, Cc.X., Chen, L.J and Duan, Z.H. 2009. Catalytic potential of soil hydrolases in north-east China under different soil moisture conditions. Journal of Soil Science and Plant Nutrition. 9 (2): $116-124$.

\section{How to cite this article:}

Aruna Kumari, J., P.C.Rao, G.Padmaja and Madhavi, M.2020. Effect of Substrate Concentration on Soil Enzyme Urease. Int.J.Curr.Microbiol.App.Sci. 9(03): 1150-1158. doi: https://doi.org/10.20546/ijcmas.2020.903.134 